\title{
ECONOMIC GROWTH IN THE WESTERN BALKANS: A PANEL ANALYSIS
}

Besime Ziberi, Merita Zulfiu Alili

\section{Abstract}

This paper investigates how typical macroeconomic indicators affect the economic growth of Western Balkans countries. A static panel empirical investigation for the period 2010 to 2019 has been conducted using GDP growth rate as the dependent variable, while independent variables in focus include foreign direct investments, remittances, unemployment rate, population growth rate, and control of corruption. The most interesting finding is that a rising share of remittances positively affects economic growth. This might indicate that even when remittances are used for non-investment purposes, they might increase domestic production of consumption and intermediate goods. There is also evidence of a non-linear relationship between FDI and economic growth, which may be a consequence of undeveloped capacities to use the positive side of FDI. To foster economic growth policy-makers should focus on reforms that target sectors that show sharp declines in FDI and remittances inflows, including also a need for better control of corruption in the region.

Keywords: Economic growth, panel data, FDI, remittances, unemployment, corruption

JEL Classification: E60, 010

\section{Introduction}

The Western Balkans countries (Northern Macedonia, Kosovo, Albania, Bosnia and Herzegovina, Montenegro, and Serbia) have transitional economic systems with many problems and challenges. During the 1990s, the Western Balkan region suffered from severe conflicts, which ended after intervention by the United Nations and NATO forces. In the early and mid-2000s, the prospect of EU accession and the global boom facilitated rapid economic recovery in the Western Balkans and boosted economic and institutional reforms (Dabrowski and Myachenkova 2018). The region is known for its instability and recent history of wars and civil conflicts. During the transition period, the WBC embarked on a process of far-reaching reforms aimed at transforming the economic structure
Besime Ziberi, PhD

Assistant Professor

Faculty of Economics, AAB College, Kosovo

E-mail: besime.ziberi@universitetiaab.com

ORCID number: 0000-0003-2891-3832

Merita Zulfiu Alili, PhD (corresponding author)

Associate Professor

Faculty of Contemporary Social Sciences,

South East European University

E-mail:m.zulfiu@seeu.edu.mk

Address: Ilindenska no. 335, 1200 Tetovo,

North Macedonia

ORCID number: 0000-0002-6367-6193 
from a socialist to a market-based one (Shimbov, Alguacil, and Suárez 2019).

Six Western Balkans countries are known as countries with young populations (but aging once due the high emigration rate of youth in the region (Efendic 2016; Michael and Isilda 2020)) and rising numbers of university graduates, on the other hand, insufficient demands for profiles from the labour market and thus high unemployment rates of persons with a university degree. According to the World Bank Group (2017), over 67 percent of respondents in the Western Balkans cited unemployment as their top concern - double the share in the European Union, where it appears that a stronger labour-market response and more generous unemployment benefits have counteracted the effects of slowing growth. Remittances and Foreign Direct Investment are considered as driving forces for sustainable economic growth and development in the WB region.

The resulting inflows of capital and technology affected the demand for labour and accordingly employment, productivity and wage levels (Zulfiu Alili and Adnett 2018). Regarding the attraction of foreign direct investments, a series of legal and economic reforms were applied to improve the business climate. However, despite the efforts of governments to improve the conditions for doing business and attract FDI, decreasing the unemployment rate thus increasing the level of employment, corruption and unemployment remain significant factors that hamper the economic stability of these countries. The main concern of any macroeconomic policy is to lower the unemployment rate and to have economic growth, so these two indicators play a vital role in the economic performance of any country (Ziberi and Avdiu 2019).

The Western Balkan countries are steadily stated in the viewpoint of economic growth with a long process of transition and concretely from the year that the countries gained the status of candidate for the European Union are still far away from negotiations to join the European Union. The transition from stagnation to growth is one way to think about the historical pattern: what can trigger such shift and what is the underlying engine of growth that could explain not just the shift from a low level of development into persistent growth in per-capita income, but also the demographic transition that has accompanied such a growth pattern in many other parts of the world in more recent decades? (Isaac and Pei 2020). The increasing trend of youth unemployment in the Western Balkans will hamper economic growth. In the long run, this will result in the loss of an important share of the human capital of these countries, which might affect their prospects for convergence with
Western European levels, including in terms of wages (Amoh, Awuah-Werekoh, and Ofori-Boateng 2020). DIG-Labour models feature segmented labour markets, efficiency wages and open unemployment, and an informal non-agricultural sector. Thus investment in education affects labour productivity with a long lag, it takes $15+$ years before net national income, the private capital stock, and real wages for the poor, and formal sector employment to surpass their counterparts in a program that invests mainly in infrastructure (Buffie et al. 2020). Thus the 2025 EU Accession target for the Western Balkans represents a highly ambitious best-case scenario, which could serve as a powerful incentive for countries in the region to speed up their reform agendas (Grieveson, Grübler, and Holzner 2018).

This study examines the factors that impact the economic growth of Western Balkans countries. Population growth, remittances, FDI and control of corruption are factors expected to boost economic growth. In the viewpoint of the determinants that negatively impact the economic growth in WB, we take into account unemployment as a main challenge that remains unsolved and a crucial factor for development.

The rest of the paper is organized as follows: In Section 2, a review of relevant previous empirical research is presented. This discussion informs the specification of the model of determinants of economic growth presented in Section 3. Section 3 also explains the data used and presents the descriptive statistics of the variables of interest. The empirical approach taken to estimate the determinants of the economic growth model is explained in Section 4. The following section presents and interprets the results, with both Fixed and Random effects models providing a robustness check. Section 6 is devoted to concluding remarks and consideration of the policy implications of the main findings.

\section{Literature Review}

Two main factors of great importance for economic growth in WB countries are Foreign Direct Investment and Remittances (Loxha 2019). For example, the effects of foreign direct investment inflows in the industrial, construction, and services sectors on economic growth are analysed from Miteski and Stefanova (2017) in a panel of sixteen Central, Eastern, and South-eastern European CESEE countries using data for the period 1998-2013. Their findings indicate that total FDI contributes positively to the growth in the countries into the analysis. 
Biørn and Han (2017) use GMM estimation of autoregressive equations in error-ridden variables with error memory considered in exploring the impact of foreign direct investment (FDI) on GDP using country panel data. Their study comes to the conclusion that results from Monte Carlo simulations suggest that aggregate FDI has a positive, but insignificant effect on aggregate GDP based on the full country panel; (2) for the developing Asian countries, FDI significantly improves GDP growth; and (3) manufacturing FDI impacts both manufacturing and service GDP growth positively.

Of a great contribution is the study from Dritsakis and Stamatiou (2018) which examines the causality relationships between foreign direct investments (FDI), exports, unemployment, and economic growth in the fifteen old EU members using panel data for the period 1970 to 2015 . The results indicate that there are three bidirectional causalities among economic growth and exports, exports and FDI, and exports and unemployment, and three unidirectional causalities running from FDI to economic growth, FDI to unemployment, and from economic growth to unemployment.

Brenner (2014) studies the effects of foreign direct investment (FDI) on national economic growth taking into consideration the effects on productivity growth, capital and labour inputs, and innovation. This study analyses separately less and more developed countries for the periods 1974-1991 and 1992-2009. Results suggest that the effects of FDI on production capacities are found to be positive for more developed countries in the first time period, while effects on innovation activities are found to be positive for the medium developed countries in the latter time period. Effects in less developed countries are rather negative. The empirical analysis of Mehic, Silajdzic, and BabicHodovic (2014) on the impact of FDI on economic growth in the transition countries of southeast Europe indicates a positive and statistically significant effect of FDI on economic growth. This effect is robust when including data on domestic investments.

A study from Djankov and Hoekman (2000) concludes that the wider benefits of FDI are contingent on the domestic economic and institutional environment - there is nothing automatic about them. Also, the study concludes that FDI in the transition economies since 1990 has largely flowed to just a few central European countries, which are also the leading candidates for EU membership. These have indeed benefited from significant FDI financing of the balance of payments, and enterprises with foreign investment, not surprisingly, have had high rates of growth of output, productivity, and exports. However, the expected spillover benefits to purely domestic enterprises which represent the broader advantages of FDI for economic development - are found to be few and far between, and indeed often appear to have been negative rather than positive. In the absence of positive spillovers - and a fortiori in the presence of negative ones - the restructuring and development of the domestic enterprise sector may be inhibited, thereby reinforcing fears that an "enclave" economy might be emerging where a technologically advanced FDI sector pulls ahead but has little if any positive impact on the rest of the economy.

The effect of Foreign Direct Investment (FDI) on economic growth is analysed by Keisuke and Sovannroeun (2010) using the data of 132 countries for the period from 1995 to 2008, considering the role of corruption in each country as an absorptive factor. The estimation results indicate that, although FDI alone does not promote economic growth, it has a significant effect on economic growth if the interaction term between FDI and corruption is examined. Tamar and Luca (2020) results suggest FDI benefits do not accrue mechanically and evenly across countries. They find an inverted-U-shaped relationship between countries' income levels and the size of FDI impact on growth. The determinants and the policies that affect economic growth in the Western Balkan are also studied by Fetai, Mustafi, and Fetai (2017) over the period 1994 to 2015. The study used OLS, fixed and random effects model, and instrumental variables (IV). The results indicate that foreign direct investments, gross savings, and domestic credit to the private sector have a positive effect on per capita growth in the case of Western Balkan Countries.

Sabir, Rafique, and Abbas (2019) analyze the impact of institutional quality on Foreign Direct Investment (FDI) inflows using panel data for low, lower-middle, upper-middle, and high-income countries for the sample period of 1996-2016 using the Generalized Method of Moments (GMM). They find that the magnitude of the coefficients of control of corruption, government effectiveness, political stability, regulatory quality, rule of law, and voice and accountability for FDI inflows are greater in developed countries compared to emerging countries. The relationship between institutional improvement and economic performance analysed by Efendic and Pugh (2015) find that GDP per capita in transition economies is determined by the history of the institutional reform and conditional on this history, GDP per capita adjusts to institutional changes.

The threshold level of corruption separating the negative and positive effects of FDI on economic growth is approximately in the 10th percentile from 
the least corrupt countries. The existence of a corruption threshold implies a counter-intuitive proposition: that FDI inhibits economic growth in countries where corruption is below a corruption threshold and promotes economic growth in countries where corruption is above the threshold. Amoh, AwuahWerekoh, and Ofori-Boateng (2020) examine the effect of corruption on economic growth in Ghana. To establish the strength of relationships among corrupting activities they used structural equation modeling on selected data from the World Economic Forum executive opinion survey on corrupting activities and data on economic growth measures from the World Development Indicators data from 2008 to 2017. The study concludes that corrupting activities, independently and mutually impede Ghana's economic growth.

Sbaouelgi (2019) examines the impact of corruption on investments and economic growth in countries from the MENA region over the period 1990 to 2017 using the dynamic panel data model. Results suggest that political institutions have a positive effect on investment and growth. Moreover, corruption harms economic growth through its impact on investment. The way how corruption impacts the economic growth of Western Balkans is also analysed through indirect channels taking into consideration the impact of corruption in Small and Medium Enterprises $s$ (SMEs) as they are considered a key factor of economic growth. SMEs impact the economic growth through job creation, innovation, and creativity, production, knowhow, etc.

The study of Rehman et al. (2019) analyses the barriers that hinder labour productivity (LP) of SMEs in WBCs. The study uses cross-sectional data and conducting a factor analysis and ordinary least square (OLS) regression. The study comes with directions that the variability for different countries' access to finance, tax rates, tax administration, corruption, inadequately educated labor force, competition in the informal sector, and political instability appears to be some of the main obstacles that are negatively affecting LP of SMEs in WBC.

Another study (Durguti et al. 2020) used panel data for the Western Balkan countries for the period 2001 to 2017 and pooled OLS methods, fixed and random effects model, to test economic growth rate as the dependent variable, and explanatory variables such as working remittances to GDP, exports to GDP, imports to GDP, foreign direct investment to GDP and inflation rate as independent variables. The study concludes that foreign direct investments and inflation do not impact the economic growth in Western Balkans countries.
Remittances and their impact on economic growth is analysed by Meyer and Shera (2017) using panel data of six high remittance-receiving countries, Albania, Bulgaria, Macedonia, Moldova, Romania, and Bosnia Herzegovina during the period 1999 to 2013. The study comes with conclusions that remittances have a positive impact on growth and that this impact increases at higher levels of remittances relative to GDP.

Astrov et al. (2020) have used the econometric vector autoregression (VAR) estimation, which takes account of endogeneity and dynamic effects. Results indicate that the Phillips curve mechanism, which transmits declining unemployment to wage dynamics, is not yet mature in less-developed countries, such as the Western Balkans, Moldova and Ukraine.

Using a set of determinants of economic growth suggested by literature in a group of transition countries from 1997 to 2017, Szymańska (2021) panel data results indicate that the effect of demographic factors are not significant, however, the role of investment has been emphasized.

Our literature review reveals the number of determinants to be important for the economic growth of WB countries, but this applies to standard growth factors, in particular to FDI, corruption, and remittances, which have specific importance in the region. Thus, we focus our empirical investigation on these influences.

\section{Model Specification, data and descriptive statistics}

Hundreds of previous empirical studies have attempted to identify the determinants of economic growth. However, as emphasized in these studies, growth theories are open-ended. Hence the diversity of theoretical views makes it difficult the identification of the most effective growth-promoting policies (Moral-Benito 2009). Based on the previous literature and data availability for the countries included in the sample the following -growth model is specified:

$\gamma_{i t}=\beta_{0}+\beta_{1} X_{i t}+e_{i t}$

Where:

$i$ indexes countries; $t$ the time period; $\gamma_{i t}$ represents the dependent variable GDP growth (annual \%); $x_{i t}$ represent a set of growth determinants, including those suggested by previous empirical studies, hence population growth rate (POP), remittances (REM), foreign direct investments (FDI), unemployment (UNR) and control of corruption (CORR), and $e_{i t}$ is the error term. 
To capture the effect of demographic changes population growth (POP) is included in the model. Population growth rate, if considered as independent from GDP growth, is expected to lead to higher economic growth rates. In this case population growth is stimulating technological innovations that would allow food production to keep up with the growing population (Wesley and Peterson, 2017). However, Malthus (1993) argues that population growth harms economic growth since the population tends to grow faster than food supplies and other goods needed for human life. High population growth in low-income countries may slow the economic growth (Wesley and Peterson 2017).

Population growth affects the age structure and the workforce of a country's population, international migration, economic inequality, etc. As shown in Table 1 , the mean of population growth (annual \%) is negative in Albania, Serbia, and Bosnia and Herzegovina, hence the population size is getting smaller for the period 2000 to 2019, mainly as a result of high emigration rates in these countries. Data reveal low population growth of $0.1 \%$ in other SEEC included in the sample. The size of the population in this region is suspicious due to high emigration rates.

Remittances (REM) are expected to contribute to economic growth through their positive impact on consumption, savings, and investments. These countries have experienced a significant increase in remittances and in most of the countries they represent more than 10 percent of GDP on average exceeding the flows of FDI. Kosovo as one of the countries with the weakest economic development in the region is more dependent on remittances (mean of $16.6 \%$ for the period 2000 to 2019) (Table 1).

The role of FDI is generally considered to impact positively economic growth. Nevertheless, as discussed above, the empirical evidence is mixed. The data in Table 1 show that FDI inflows during the past decade in Western Balkan countries have been stagnant on average. Among the countries included in the sample, Montenegro has been more successful in attracting FDI for the period under investigation with a mean of $15.5 \%$ of GDP. FDI squared is added to test for any non-linearity in the relationship with the GDP growth.

Unemployment (UNR) is a macroeconomic indicator having high values (the mean value in the sample is $25 \%$, Table 1) presents the inability of these economies to make full use of labour resources. Kosovo experienced the highest unemployment rate (mean of $40.1 \%$ ) among the other Western Balkans countries.

Corruption leads to high investments costs and low profit, hence discouraging investments and affecting negatively the economic growth. Whereas control of corruption (CORR) and government effectiveness are expected to positively impact economic growth. All data are obtained from the World Bank Indicators (The World Bank 2020). Analysing the rank of control of corruption for the period 2000 to 2019 for the countries under investigation the data show that Albania went down by 9.3 in rank for control of corruption, Montenegro went down by 1.9 in rank and Serbia went down by 29.4 in rank. Whereas Bosnia and Herzegovina went up by 3.2 in rank and Kosovo went up by 37.3 in rank for control of corruption.

Among the selected countries, Albania has the highest year-on-year average growth rate at $3.96 \%$, whereas North Macedonia has the lowest year-onyear average growth rate at $-53.99 \%$. Appendix 1 presents more details on variable definitions and data sources.

\section{Empirical methodology}

The empirical methodology used to select the correct estimation technique is discussed in this section. We compared the Ordinary Least Squares (OLS), Fixed Effects (FE), and Random Effects (RE) models for panel data using the standard approach. Both the FE and the RE models appear to be appropriate estimators, as discussed below. The preferred model is FE, which is more appropriate for small samples and can be estimated for unbalanced panels, as is the case here, whereas RE is estimated as a robustness check. Diagnostic tests were performed on the chosen model to check if it is misspecified. The slope homogeneity, cross-sectional dependence in the error, groupwise heteroscedasticity, serial correlation in the errors, and normality of the errors have all been evaluated as common concerns with panel estimations. These tests are explained below and summarised in Appendix 3 . To account for the heteroscedasticity problem, robust standard errors are used.

To explore the determinants of economic growth, we start with the classic OLS estimator testing whether fixed effects model is more appropriate than OLS. To choose between these two models we test whether the deviations (FEs) are jointly significant. Results presented in Appendix 2 indicate that a one-way FEM is supported. The use of the OLS model would produce unreliable estimates since heterogeneity across countries exists. Choosing between one-way RE versus OLS, Breusch and Pagan's LM statistic is performed. In this case $\mathrm{HO}: \mathrm{s} 2 \mathrm{u}=0$ with test restriction that $\mathrm{ui}=\alpha$ (whether random effects are equal to OLS intercept). The result of the test indicates the estimation of RE compared 
Table1. Summary statistics of the variables of interest by country and total, 2000-2019

\begin{tabular}{|c|c|c|c|c|c|}
\hline & $\mathrm{N}$ & mean & sd & $\min$ & $\max$ \\
\hline \multicolumn{6}{|l|}{ Albania } \\
\hline GDP growth & 20 & 4.3 & 2.1 & 1.0 & 8.3 \\
\hline Population growth (POP) & 20 & -0.4 & 0.2 & -0.9 & -0.1 \\
\hline Remittances (REM) & 20 & 13.4 & 2.8 & 9.6 & 17.8 \\
\hline Foreign Direct Investment (FDI) & 20 & 6.9 & 2.5 & 3.1 & 11.2 \\
\hline Unemployment rate (UNR) & 20 & 15.2 & 1.7 & 12.3 & 17.5 \\
\hline Corruption rank (CORR) & 19 & 30.8 & 6.3 & 22.9 & 42.3 \\
\hline \multicolumn{6}{|l|}{ Bosnia and Herzegovina } \\
\hline GDP growth & 20 & 3.4 & 2.7 & -3.0 & 8.8 \\
\hline Population growth (POP) & 20 & -0.6 & 0.7 & -1.7 & 0.2 \\
\hline Remittances (REM) & 20 & 15.3 & 5.7 & 10.5 & 28.7 \\
\hline Foreign Direct Investment (FDI) & 20 & 3.8 & 2.6 & 0.8 & 11.7 \\
\hline Unemployment rate (UNR) & 20 & 26.2 & 3.6 & 18.4 & 31.1 \\
\hline Corruption rank (CORR) & 19 & 42.4 & 6.0 & 30.3 & 50.7 \\
\hline \multicolumn{6}{|l|}{ Kosovo } \\
\hline GDP growth & 19 & 5.2 & 5.6 & -0.7 & 27.0 \\
\hline Population growth (POP) & 20 & 0.1 & 1.0 & -3.6 & 0.9 \\
\hline Remittances (REM) & 16 & 16.6 & 2.0 & 14.6 & 20.1 \\
\hline Foreign Direct Investment (FDI) & 16 & 5.9 & 3.1 & 1.5 & 13.0 \\
\hline Unemployment rate (UNR) & 19 & 40.1 & 9.6 & 25.6 & 57.0 \\
\hline Corruption rank (CORR) & 19 & 38.5 & 11.8 & 26.7 & 69.7 \\
\hline \multicolumn{6}{|l|}{ North Macedonia } \\
\hline GDP growth & 20 & 2.9 & 2.3 & -3.1 & 6.5 \\
\hline Population growth (POP) & 20 & 0.1 & 0.1 & 0.0 & 0.5 \\
\hline Remittances (REM) & 20 & 3.3 & 0.7 & 2.0 & 4.1 \\
\hline Foreign Direct Investment (FDI) & 20 & 4.6 & 2.6 & 0.5 & 12.7 \\
\hline Unemployment rate (UNR) & 20 & 30.2 & 5.6 & 17.8 & 37.2 \\
\hline Corruption rank (CORR) & 19 & 45.6 & 9.7 & 26.8 & 57.3 \\
\hline \multicolumn{6}{|l|}{ Montenegro } \\
\hline GDP growth & 20 & 3.1 & 3.2 & -5.8 & 8.6 \\
\hline Population growth (POP) & 20 & 0.1 & 0.1 & -0.0 & 0.4 \\
\hline Remittances (REM) & 13 & 10.1 & 2.3 & 5.3 & 12.4 \\
\hline Foreign Direct Investment (FDI) & 13 & 15.5 & 8.7 & 5.2 & 37.3 \\
\hline Unemployment rate (UNR) & 20 & 22.1 & 6.0 & 14.9 & 30.6 \\
\hline Corruption rank (CORR) & 19 & 50.9 & 5.7 & 38.0 & 58.2 \\
\hline \multicolumn{6}{|l|}{ Serbia } \\
\hline GDP growth & 20 & 3.6 & 3.0 & -2.7 & 9.0 \\
\hline Population growth (POP) & 20 & -0.4 & 0.2 & -0.8 & -0.1 \\
\hline Remittances (REM) & 13 & 8.4 & 0.9 & 6.8 & 10.3 \\
\hline Foreign Direct Investment (FDI) & 13 & 6.5 & 2.3 & 2.9 & 10.2 \\
\hline Unemployment rate (UNR) & 20 & 17.1 & 3.8 & 12.6 & 24.0 \\
\hline Corruption rank (CORR) & 19 & 41.6 & 10.3 & 7.6 & 51.4 \\
\hline \multicolumn{6}{|l|}{ Total } \\
\hline GDP growth & 119 & 3.7 & 3.3 & -5.8 & 27.0 \\
\hline Population growth (POP) & 120 & -0.2 & 0.6 & -3.6 & -0.9 \\
\hline Remittances (REM) & 102 & 11.2 & 5.6 & 2.0 & 28.7 \\
\hline Foreign Direct Investment (FDI) & 102 & 6.7 & 5.2 & 0.5 & 37.3 \\
\hline Unemployment rate (UNR) & 119 & 25.0 & 10.0 & 12.3 & 57.0 \\
\hline Corruption rank (CORR) & 114 & 41.6 & 10.5 & 7.6 & 69.7 \\
\hline
\end{tabular}

Source: (The World Bank, 2020), Author's calculations 
to OLS. Besides, the OLS does not account for the group-specific effects. The last models to be tested are a one-way FEM vs. one-way REM. To decide between these two models Hausman's chi-square statistic can be used. A large value from this test will support FE over RE. Here, we test the null hypothesis that the unobserved individual-specific random effects and regressors are uncorrelated. The test suggests that random effects can be estimated. According to this test, the difference between the estimators is small to its variance, i.e. there is no systematic difference between the estimators, which suggests that the RE estimator is not biased and it is consistent. Therefore, in addition to the FE model, we estimate RE model.

However, we cannot totally exclude the possibility that the chosen determinants of the economic growth model might be considered to be endogenous or that we omit some important variables (e.g. institutions). FDI can lead in capital accumulation and increase employment opportunities but also would contribute to increasing the economic growth of the host economy. However, there is no clarity on the direction of causality between FDI and economic growth in the literature. There is no consensus on whether economic growth causes FDI or FDI causes economic growth (Sabharwal 2019). Previous studies find institutions to be an important factor for economic growth and development, they should be included in econometric models to account for transaction costs (Efendic and Pugh 2007; Efendic and Pugh 2015).

However, institution measures (mainly used in the literature EBRD indices) for countries in the sample are missing for some years and especially for Kosovo which reduced significantly the number of observations making it not reliable to include in the model. According to Wooldridge (2002), endogeneity occurs when variables are omitted because data is unavailable; measurement error occurs when a variable's (partial) effect is measured with only an imperfect measure of it; and simultaneity occurs when at least one of the explanatory variables is determined simultaneously with the dependent variable. The GMM estimator presented by Arellano and Bond (1991), Arellano and Bover (1995), Blundell and Bond (1998), Roodman (2009), is one technique to cope with the endogeneity problem. This model is applicable for situations with "small $\mathrm{T}$, large $\mathrm{N}$ panels, meaning few periods and many individuals; independent variables that are not strictly exogenous, meaning correlated with past and possibly current realizations of the error; fixed effects; and heteroskedasticity and autocorrelation within individuals," as Roodman argues (p.86), which is not the case in the current study since $\mathrm{N}$ is only six groups. Instrumental variable (IV) methods are another way of dealing with the endogeneity problem (Baltagi 2005 , p. 113). However, given the limitations of the available data finding a good instrumental variable for an endogenous explanatory variable in this case is very difficult. Assuming that the correlation of FDI with the error term is fixed over time, the problem of potential endogeneity is alleviated by controlling for country fixed effects (Figini and Görg 2011; Zulfiu Alili 2021). For this reason, a Fixed Effects model has been employed.

Diagnostic testing should be used to provide the best possible statistical specification. Diagnostics for panel analysis, particularly for unbalanced and small panels like the one we have here are not well developed. Diagnostic testing, on the other hand, can still provide some valuable indicators; hence diagnostics have been used on the chosen FE model (Appendix 3).

To test for slope homogeneity a random coefficients model by GLS is estimated. This model provides the test of parameter constancy: $\mathrm{H}_{0}: \beta_{i}=\beta$. where the minimum requirement is $T>K$ (where $K$ is the number of parameters to be estimated). As expected the test indicates no slope homogeneity, however as suggested by Pesaran, Shin, and Smith (1996) this is not a problem since we are interested in investigating the determinants of growth in the countries in the sample and we are not interested in making inferences to a wider population or on the individual country coefficients. Panel data models are likely to exhibit cross-sectional dependence in the errors due to spatial dependence, omitted unobserved common components, or idiosyncratic pair-wise dependence of the error term (Pesaran 2004). There are two alternative approaches commonly used to test for cross-sectional dependence in panels, namely the Lagrange multiplier (LM) test developed by Breusch and Pagan valid when $\mathrm{T}>\mathrm{N}$ and Pesaran test valid when $\mathrm{T}<\mathrm{N}$. However, both approaches are problematic with unbalanced panel data. We have used the user-written Stata program xtcsd which allows two options in our case: the Pesaran and Friedman version of cross-sectional independence in the errors. The tests indicate to reject the Ho of zero cross-sectional dependence in the errors. Testing for homoscedasticity, i.e. constant variance over cross-section units, the modified Wald test for GroupWise heteroskedasticity was used. The null hypothesis of homoscedasticity was rejected suggesting the estimation of the model with robust standard errors. To obtain consistent estimates in addition to robust standard errors the Driscoll-Kraay standard errors are used, which are robust to heteroscedasticity Hoechle 2007). Even though autocorrelation in the errors is common in panel data analysis, the Wooldridge test for serial correlation (xtserial) suggests that 
there is no first-order autocorrelation in the errors. Normality of the errors is tested using the Stata userwritten command pantest 2 and by plotting the residuals (Appendix 3). Both the test and the plot indicate that residuals are normally distributed. The empirical results are discussed in the next section.

\section{Estimation Results}

The estimation results of the FE and RE models are presented in this section. The results of FE regressions utilizing robust standard errors and Driscoll-Kraay standard errors are shown in columns (1) and (2). The results of the RE estimation are shown in column (3) The total number of observations in the model has been decreased to 99 due to missing observations for various variables in specific years and countries.
Overall, the results are robust and do not differ significantly in terms of the magnitude and significance of the coefficients. Considering the above discussion of the heteroscedasticity problem the preferred model is FE Driscoll-Kraay standard errors, column 2. According to the findings, remittances have a favourable impact on economic growth, which is consistent with previous research. A 1 percent rise in remittances (percent of GDP) will result in a 0.3 percent boost in GDP growth for the WB nations in the sample. FDI coefficient is positive and significant suggesting that if the share of FDI to GDP increases by 1 percent economic growth will increase by 0.6 percent. However, the square FDI is negative and significant, implying that FDI and economic growth have a concave connection. As a result, FDI inflows boost economic growth (but at a slower pace). These findings could indicate that the transition countries in the sample are unable to catch up with

Table 2. Estimation results of FE and RE models.

\begin{tabular}{|c|c|c|c|}
\hline & $\begin{array}{l}\text { FE Robust standard } \\
\text { errors } \\
\text { (1) }\end{array}$ & $\begin{array}{l}\text { FE Drisc/Kraay } \\
\text { Std.Err. } \\
(2)\end{array}$ & $\begin{array}{l}\mathrm{RE} \\
(3)\end{array}$ \\
\hline VARIABLES & GDP growth & GDP growth & GDP growth \\
\hline \multirow[t]{2}{*}{ Population growth (POP) } & -0.783 & -0.783 & 0.125 \\
\hline & $(0.623)$ & $(0.418)$ & $(0.501)$ \\
\hline \multirow[t]{2}{*}{ Remittances (REM) } & $0.300^{* * *}$ & $0.300^{* * *}$ & 0.072 \\
\hline & $(0.089)$ & $(0.067)$ & $(0.046)$ \\
\hline \multirow[t]{2}{*}{ Foreign Direct Investment (FDI) } & $0.571^{* * *}$ & $0.571^{* *}$ & $0.421^{* * *}$ \\
\hline & $(0.131)$ & $(0.204)$ & $(0.116)$ \\
\hline \multirow[t]{2}{*}{ SQFDI } & $-0.017^{* * *}$ & $-0.017^{* *}$ & $-0.014^{* * *}$ \\
\hline & $(0.004)$ & $(0.005)$ & $(0.004)$ \\
\hline \multirow[t]{2}{*}{ Unemployment rate (UNR) } & -0.027 & -0.027 & 0.028 \\
\hline & $(0.050)$ & $(0.033)$ & $(0.030)$ \\
\hline \multirow[t]{2}{*}{ Corruption rank (CORR) } & $-0.080^{* *}$ & $-0.080^{* *}$ & $-0.058^{* *}$ \\
\hline & $(0.034)$ & $(0.024)$ & $(0.025)$ \\
\hline \multirow[t]{2}{*}{ Constant } & 1.263 & 1.263 & 2.564 \\
\hline & $(2.057)$ & $(1.233)$ & $(1.599)$ \\
\hline Observations & 99 & 99 & 99 \\
\hline R-squared & 0.341 & & \\
\hline Number of id & 6 & & 6 \\
\hline Number of groups & & 6 & \\
\hline
\end{tabular}

Robust standard errors in parentheses

${ }^{* * *} p<0.01,{ }^{* *} p<0.05,{ }^{*} p<0.1$

Source: Author's calculations 
the trend of technological inventiveness and expertise, causing domestic enterprises to be constrained and unable to achieve market share competitiveness. Melnyk, Kubatko, and Pysarenko (2014) find that additional FDI inflows in firms may push out of the market other firms without FDI, this is referred to as a "market stealing" effect when domestic firms are not so productive compared to the foreign ones. Western Balkan countries in recent years have decreasing trends of FDI in general and also in regard to technology and knowhow which are considered as main channels through which FDI is expected to positively impact growth. In this regard, results might suggest that FDI investments should be oriented to productive sectors thus increasing the rate of employment and productivity in the labor market. In addition, the negative sign of square FDI might be a consequence of the relatively high level of corruption in many transition countries ${ }^{1}$. In addition, the unemployment rate is used as an independent variable, which is also an outcome variable. Including the unemployment rate raises the question: does reducing the unemployment rate increases a real GDP growth or does real GDP growth causes a reduction in unemployment or do both affect one another. However, the unemployment variable is not significant and excluding it from the model does not impact the results. A low level of control of corruption may humper the positive effect that FDI may have on human development and economic growth. Evidence indicates that corruption is likely to adversely affect long-term economic growth through its impact on investment, taxation, public expenditures, and human development. Corruption is also likely to undermine the regulatory environment and the efficiency of state institutions as rent-seeking distorts incentives and decision-making processes (Chêne 2014). The variable of control of corruption is negative and significant indicating that a one percent increase of control of corruption will negatively impact the economic growth by 0.08 percent. Ahmad, Ullah and Arfeen (2012) show that a decrease in corruption raises the economic growth rate in an inverted U-shaped way. They find corruption to be growth-enhancing at low levels of incidence and growth-reducing at high levels of incidence.

It should be emphasized that the relatively small size of the sample in this study affects the number of possible variables to be included in the growth analysis, due to the data availability. Therefore, the role of institutions in explaining economic growth could not be included. As indicated above a dynamic panel model could be an advantage to account for endogeneity which arises due to omitted variables that not be included due to data unavailability, however, this was not possible in our case. A bigger sample would be an advantage in the future, taking into account also the effect of the Pandemic.

\section{Conclusions and Recommendations}

This study analyses the impact of macroeconomic indicators on economic growth in Western Balkans countries. The factors influencing economic growth are divided into two groups: factors expected to positively impact economic growth such as population growth rate, remittances, Foreign Direct Investments, control of corruption and one of the main factors that hamper the economic growth such as unemployment. Using data from World Bank Indicators for the period 2000 to2019 we estimated FE and RE models. Results suggest that remittances and FDI positively impact the economic growth of the Western Balkan countries whereas unemployment and control of corruption have a negative impact on the economic growth. This study suggests that remittances are an important factor for economic growth and they should be more oriented to investment instead of personal consumption. The study also suggests for policymakers to build business zones and also to improve the rule of law in order to attract the FDI. Economic growth increases with FDI inflow but this effect diminishes with further increases in FDI. A study from (Jushi et al. 2021) concludes that in the case of Western Balkans countries, remittances; population growth, and labour force participation were not key determinants of growth. The impact of FDI and trade was negative yet highly significant. As far as GDP growth, it exhibited strong persistence from one year to the next. Trying to keep stable remittances, FDI, and trade over time can make these factors have a positive significant contribution to growth. In addition, these countries are steadystate in the road of the process of automation and digitalization whereas domestic firms usually remain out of the competitive market in front of foreign firms.

Western Balkans countries are late with the harmonization of legal acts and even more in delay with the implementation of innovations. Having in mind the nature of the process of digitalization, it should go in line with the market requests otherwise it threatens to remain at all times outdated and too expensive. Furthermore, the digitalization of services in the Western Balkans region is mostly driven by the financial aspect and most of the electronic services (eservices) provided are intended for the business sector (Jashari 2020).

In sum, the previous empirical evidence supports the hypothesis that an increased FDI inward stock as 
a share of GDP increases economic growth; however, this relationship may be a complex one in transition economies. This study highlights for policymakers to make efforts on reduction of corruption as mainly the corruption affects also the trend of FDI and in general hampers the economic growth of WB countries.

As a result of the pandemic crisis, all countries in the region have moved to support enterprises to retain jobs and protect the unemployed and as the recovery phase starts, authorities there should not lose sight of addressing longer-term challenges (World Bank Group 2020). The COVID-19 pandemic and the ensuing economic crisis have exposed how informal firms and workers are more vulnerable to shocks, and the difficulty of providing support to businesses operating in the shadow (informal) economy. All six Western Balkan economies have large informal sectors, which account for an estimated 25-35 percent of both the GDP and the number of people employed - much higher than in the EU member states. For the Western Balkan economies, high informality has held back growth, created unfair competition, and delayed convergence with the rest of Europe (World Bank Group 2021).

Government reforms need to be oriented toward the reduction of high unemployment rates through creating jobs and promote youth employment through creativity and innovation as key drivers of economic growth in these countries. The study goes further with recommendations for policy-making in the Western Balkan countries to strengthen law enforcement, reduce corruption, apply policies to raise public awareness to ask for fiscal coupons when making purchases, promote democratic and economic sustainability to attract foreign investors in exportoriented industries, regulate contract issues in economic zones and facilitate administrative procedures for foreign investors and to use private remittances for business purposes in this way to generate new jobs.

\section{Endnotes}

1 We included an interaction term between FDI and corruption, however, in this case the model was not well specified and the coefficient of interaction term was not significant.

\section{References}

Ahmad, E., Ullah, M. A. and Arfeen, M. I. 2012. Does corruption affect economic growth?. Latin American Journal of Economics 49(2): 277-305.

Amoh, J. K., Awuah-Werekoh, K. and Ofori-Boateng, K. 2020. Do corrupting activities hamper economic growth?. Journal of Financial Crime. https://doi.org/10.1108/ JFC-11-2019-0150.

Arellano, M. and Bond, S. 1991. Some tests of specification for panel data: Monte Carlo evidence and an application to employment equations. Review of Economic Studies 58: 277-297.

Arellano, M. and Bover , O. 1995. Another look at the instrumental variable estimation of error-components models. Journal of Econometrics 68: 29-51.

Astrov, V., Leitner S., Mara, I., Podkaminer, L., and Weinberger, V. H. 2020. Wage developments in the Western Balkans, Moldova and Ukraine, Vienna: The Vienna Institute for International Economic Studies (wiiw) 444.

Baltagi, B. 2005. Econometric analysis of panel data. Chichester: John Wiley and Sons.

Bartlett, W. 2008. Europe's troubled region: economic development, institutional reform and social welfare in the Western Balkans. London: Routledge.

Biørn, E. and Han, X. 2017. Revisiting the FDI impact on GDP growth in errors-in-variables models: a panel data GMM analysis allowing for error memory. Empirical Economics: A Journal of the Institute for Advanced Studies.

Blundell, R. and Bond, S. 1998. Initial conditions and moment restrictions in dynamic panel data models. Journal of Econometrics 87:115-143.

Brenner, T. 2014. The impact of foreign direct investment on economic growth: an empirical analysis of different effects in less and more developed countries. Marburg: Philipps University Marburg, Department of Geography.

Buffie, E. F., Luis-Felipe, Z., Christopher, A., Lacina, B., Dawit, T., and Kangni, K. 2020. Debt, investment, and growth in developing countries with segmented labor markets. Washington, DC: International Monetary Fund / IMF Working Paper.

Chêne, M. 2014. The Impact of corruption on growth and inequality. Transparency International.

Dabrowski, M. and Myachenkova, Y. 2018. The Western Balkans on the road to the European Union. Bruegel Policy Contribution 4.

Djankov, S. and Hoekman, B. 2000. Foreign investment and productivity growth in Czech enterprises. Economic Survey of Europe 14(1): 49-64.

Dritsakis, N. and Stamatiou, P. 2018. Causal nexus between FDI, exports, unemployment and economic growth for the old European Union members: evidence from panel data. International Journal of Economic Sciences: IJoES. 
Durguti, E. A., Gashi, E., Kunoviku, F. D. and Mehmeti, M. 2020. DAF determinants affecting economic growth evidence for Western Balkans countries. International Journal of Finance and Banking Studies: JJFBS, 9(1).

Efendic, A. and Pugh, G. 2015. Institutional effects on economic performance in post-socialist transition: a dynamic panel analysis. Acta Oeconomica 65(4): 503-523.

Efendic, A. 2016. Emigration intentions in a post-conflict environment: evidence from Bosnia and Herzegovina. Post-Communist Economies 28(3): 335-352.

Efendic, A. and Pugh, G. 2007. Institutions and economic performance: an overview of empirical research with the main focus on transition economies. SEE Journal of Economics and Business 2(1):. 25-30.

Fetai, B. T., Mustafi, B. F. and Fetai, A. B. 2017. An empirical analysis of the determinants of economic growth in the Western Balkans. Scientific Annals of Economics and Business 245-254.

Figini, P. and Görg, H. 2011. Does foreign direct investment affect wage inequality? An empirical investigation. The World Economy 34(9): 1455-1475.

Grieveson, R., Grübler, J., G. and Holzner, M. 2018. Western Balkans EU accession: is the 2025 target date realistic?, Vienna: The Vienna Institute for International Economic Studies (wiiw).

Hoechle, D. 2007. Robust standard errors for panel regressions with cross-sectional dependence. The Stata Journal 7(3): 281-312.

Isaac, E. and Pei, Y. 2020. Human capital as engine of growth: the role of knowledge transfers in promoting balanced growth within and across countries, Germany: Discussion paper series/IZA.

Jashari, B. 2020. Digital agenda absorvatory. Regional Baseline Research.

Jushi, E., Hysa, E., Panait, M. and Voica, M. C. 2021. Financing growth through remittances and foreign direct investment: evidences from Balkan countries. Journal of Risk anf Financial Management 14(3).

Keisuke, O. and Sovannroeun, S. 2010. How Does corruption influence the effect of foreign direct investment on economic growth?. s.l.:Munich Personal RePEc Archive.

Loxha, A. 2019. Do remittances reduce poverty in Kosovo?A counterfactual analysis. The South East European Journal of Economics and Business 14(2): 117-132.

Malthus, T. 1993. An essay on the principle of population. New York: Oxford Press.

Mehic, E., Silajdzic, S. and Babic-Hodovic, V. 2014. The impact of FDI on economic growth: some evidence from Southeast Europe. Emerging Markets Finance and Trade 49(1): 5-20.

Melnyk, L., Kubatko, O. and Pysarenko, S. 2014. The impact of foreign direct investment on economic growth: case of post communism transition economies. Problems and Perspectives in Management 12(1).
Meyer, D. and Shera, A. 2017. The impact of remittances on economic growth: an econometric model. Economia. Revista da ANPEC 18(2): 147-155.

Michael, L. and Isilda, M. 2020. Massive migration and its effect on human capital and growth: the case of Western Balkan and Central and Eastern European countries. Vienna: The Vienna Institute for International Economic Studies (wiiw).

Miteski, M. and Stefanova, D. J. 2017. The impact of sectorial FDI on economic growth in Central, Eastern and Southeastern Europe. Skopje: National Bank of the Republic of Macedonia.

Moral-Benito, E. 2009. Determinants of economic growth. A Bayesian Panel data approach. Policy Research Working Paper 4830: The World Bank.

Pesaran, M. H. 2004. General diagnostic tests for cross section dependence in panels. Faculty of Economics, University of Cambridge, Cambridge Working Papers in Economics 0435.

Pesaran, M. H., Shin, Y. and Smith, R. J. 1996. Testing for the 'existence of a long-run relationship': University of Cambridge.

Rehman, N. U., Çela, A., Morina, F. and Gura, K. S. 2019. Barriers to growth of SMEs in Western Balkan countries. Journal of Management Development 38(1).

Roodman, D. 2009. How to do xtabond2: An introduction to difference and system GMM in Stata. The Stata Journal 9(1): 86-136.

Sabharwal, K. 2019. Causal link between FDI and economic growth? Panel data analysis of MINT economies. International Journal of Business Analytics and Intelligence 7(2): 35-41.

Sabir, S., Rafique, A. and Abbas, K. 2019. Institutions and FDI: evidence from developed and developing countries. Financial Innovation: FIN, 5(8): 1-20.

Sbaouelgi, J. 2019. The impact of corruption on economic growth in MENA region. Romanian Economic and Business Review 40-54.

Shimbov, B., Alguacil, M. and Suárez, C. 2019. Export structure upgrading and economic growth in the Western Balkan countries. Emerging Markets Finance and Trade 55(10): 2185-2210.

Szymańska, A. 2021. Economic performance in post-soviet and post-communist countries-evidence from panel data and multivariate statistical analysis. The South East European Journal of Economics and Business 16(2): 1-16.

Tamar, B. and Luca, G. 2020. Impact of FDI on economic growth: the role of country income levels and institutional strength. European Investment Bank (EIB).

The World Bank, 2020. World Bank Indicators. Available at: ttps://data.worldbank.org/indicator (accessed January 26, 2021)

The World Bank, 2020. World Bank Open Data: World Bank (accessed January 26, 2021). 
Wesley, E. and Peterson, F. 2017. The Role of population in economic growth. SAGE Open 7(4): 1-15.

Wooldridge, J. 2002. Econometric analysis of cross section and panel data. Cambridge: The MIT Press.

World Bank Group, 2017. Job creation picks up: World Bank.

World Bank Group, 2020. Recovery of Western Balkans firms: crowding in private investment and expanding access to advisory support, s.l.: Western Balkans Regular Economic Report 18.

World Bank Group, 2021. Subdued recovery, s.l.: The World Bank.

Ziberi, B. and Avdiu, M. 2019. Econometric analysis to examine the relationship between unemployment and macroeconomics aggregates: evidence from Kosovo. Academic journal of economic studies 6(2): 33-41.
Zulfiu Alili, M. 2021. The Impact of foreign ownership on wage inequality and skill intensity. Germany: LAP LAMBERT Academic Publishing .

Zulfiu Alili, M. and Adnet, N. 2018. Did FDI increase wage inequality in transition economies?. International Journal of Social Economics 54(9): 1283-1304. 
Appendix 1. Variables definition and the source of data

\begin{tabular}{|c|c|c|c|}
\hline $\begin{array}{l}\text { Variable } \\
\text { name }\end{array}$ & Variable label & Variable definition & Data source \\
\hline GDP & $\begin{array}{l}\text { GDP growth (an- } \\
\text { nual \%) }\end{array}$ & $\begin{array}{l}\text { Annual percentage growth rate of GDP at market prices based on } \\
\text { constant local currency. Aggregates are based on constant } 2010 \\
\text { U.S. dollars. GDP is the sum of gross value added by all resident } \\
\text { producers in the economy plus any product taxes and minus any } \\
\text { subsidies not included in the value of the products. It is calculated } \\
\text { without making deductions for depreciation of fabricated assets or } \\
\text { for depletion and degradation of natural resources. }\end{array}$ & $\begin{array}{l}\text { World Bank } \\
\text { Indicators }\end{array}$ \\
\hline POP & $\begin{array}{l}\text { Population } \\
\text { growth rate }\end{array}$ & $\begin{array}{l}\text { Annual population growth rate for year } t \text { is the exponential rate } \\
\text { of growth of midyear population from year } t-1 \text { to } t \text {, expressed as } \\
\text { a percentage. Population is based on the de facto definition of } \\
\text { population, which counts all residents regardless of legal status or } \\
\text { citizenship. }\end{array}$ & $\begin{array}{l}\text { World Bank } \\
\text { Indicators }\end{array}$ \\
\hline REM & Remittances & $\begin{array}{l}\text { Personal remittances comprise personal transfers and compensa- } \\
\text { tion of employees. Personal transfers consist of all current transfers } \\
\text { in cash or in kind made or received by resident households to or } \\
\text { from non-resident households. Personal transfers thus include } \\
\text { all current transfers between resident and non-resident individu- } \\
\text { als. Compensation of employees refers to the income of border, } \\
\text { seasonal, and other short-term workers who are employed in an } \\
\text { economy where they are not resident and of residents employed } \\
\text { by non-resident entities. Data are the sum of two items defined in } \\
\text { the sixth edition of the IMF's Balance of Payments Manual: personal } \\
\text { transfers and compensation of employees. }\end{array}$ & $\begin{array}{l}\text { World Bank } \\
\text { Indicators }\end{array}$ \\
\hline FDI & $\begin{array}{l}\text { Foreign Direct } \\
\text { Investment }\end{array}$ & $\begin{array}{l}\text { Foreign direct investment are the net inflows of investment to ac- } \\
\text { quire a lasting management interest ( } 10 \text { percent or more of voting } \\
\text { stock) in an enterprise operating in an economy other than that of } \\
\text { the investor. It is the sum of equity capital, reinvestment of earn- } \\
\text { ings, other long-term capital, and short-term capital as shown in } \\
\text { the balance of payments. This series shows net inflows (new invest- } \\
\text { ment inflows less disinvestment) in the reporting economy from } \\
\text { foreign investors, and is divided by GDP. }\end{array}$ & $\begin{array}{l}\text { World Bank } \\
\text { Indicators }\end{array}$ \\
\hline UNR & $\begin{array}{l}\text { Unemployment, } \\
\text { total (\% of } \\
\text { total labour } \\
\text { force) (national } \\
\text { estimate) }\end{array}$ & $\begin{array}{l}\text { Unemployment is defined as the percentage of the workforce that } \\
\text { is unemployed but looking for job. The terms "labor force" and "un- } \\
\text { employment" are defined differently in different countries. }\end{array}$ & $\begin{array}{l}\text { World Bank } \\
\text { Indicators }\end{array}$ \\
\hline CORR & $\begin{array}{l}\text { Control of } \\
\text { corruption }\end{array}$ & $\begin{array}{l}\text { Control of Corruption captures perceptions of the extent to which } \\
\text { public power is exercised for private gain, including both petty } \\
\text { and grand forms of corruption, as well as "capture" of the state by } \\
\text { elites and private interests. Percentile rank indicates the country's } \\
\text { rank among all countries covered by the aggregate indicator, with } \\
0 \text { corresponding to lowest rank, and } 100 \text { to highest rank. Percentile } \\
\text { ranks have been adjusted to correct for changes over time in the } \\
\text { composition of the countries covered by the WGI. Higher 'control of } \\
\text { corruption' percentile ranks denote lower corruption. }\end{array}$ & $\begin{array}{l}\text { World Bank } \\
\text { Indicators index }\end{array}$ \\
\hline
\end{tabular}


Appendix 2. Comparison of OLS, FE and RE

\begin{tabular}{|c|c|c|c|c|c|}
\hline Tests & T-statistic (TS) & Prob. & $<>$ & CV (5\%) & Decision \\
\hline F test that all $u_{-} \mathrm{i}=0$ : & $F(5,87)=2.74$ & 0.02 & $>$ & 2.32 & $\begin{array}{l}\text { If TS }>C V \rightarrow \text { Reject } \mathrm{H}_{0} \\
\text { (Supports Fixed Effects) }\end{array}$ \\
\hline$H_{0}: \sigma^{2} u=0$ & $\operatorname{chi} 2(1)=91.73$ & 0.00 & $>$ & 3.84 & $\begin{array}{l}\text { If TS }>C V \rightarrow \text { Reject } \mathrm{H}_{0} \\
\text { (Supports Random Effects) }\end{array}$ \\
\hline $\begin{array}{l}\text { Ho: difference in coefficients } \\
\text { not systematic }\end{array}$ & $\operatorname{chi} 2(6)=8.68$ & 0.18 & $>$ & 12.59 & $\begin{array}{l}\text { If } \mathrm{TS}<\mathrm{CV} \rightarrow \text { There is insufficient } \\
\text { evidence to reject } \mathrm{H}_{0} \\
\text { (RE can be estimated) }\end{array}$ \\
\hline
\end{tabular}

Source: Author's calculations

Appendix 3. Model diagnostics and plot of the residuals

\begin{tabular}{|c|c|c|c|c|c|}
\hline Tests & T-statistic (TS) & Prob. & $<>$ & CV (5\%) & Decision \\
\hline $\begin{array}{l}\text { Slope homogeneity } \\
\mathrm{H}_{\mathrm{o}}: \beta \mathrm{i}=\beta\end{array}$ & $\operatorname{chi} 2(35)=185.17$ & 0.00 & $>$ & 49.80 & $\begin{array}{l}\text { If TS }>C V \rightarrow \text { Reject } \mathrm{H}_{0} \\
\text { (No slope homogeneity) }\end{array}$ \\
\hline $\begin{array}{l}\text { Cross-sectional depen- } \\
\text { dence in the errors }\end{array}$ & Pesarans's test $=7.42$ & 0.00 & & & Both tests suggest to reject $\mathrm{H}_{0}$. \\
\hline $\begin{array}{l}\mathrm{H}_{\mathrm{o}}: \text { Zero cross-sectional } \\
\text { dependence }\end{array}$ & Friedman's test $=42.41$ & 0.00 & & & \\
\hline $\begin{array}{l}\text { Groupwise } \\
\text { heteroskedasticity } \\
\mathrm{H}_{\mathrm{o}}: \text { Homoscedasticity }\end{array}$ & $\operatorname{chi2}(6)=74.34$ & 0.00 & $>$ & 12.59 & $\begin{array}{l}\text { If TS }>C V \rightarrow \text { Reject } \mathrm{H}_{0} \\
\text { (Heteroskedasticity) }\end{array}$ \\
\hline $\begin{array}{l}\text { Serial correlation } \\
\mathrm{H}_{\mathrm{o}} \text { :No } 1^{\text {st }} \text { order } \\
\text { autocorrelation }\end{array}$ & $F(1,5)=2.83$ & 0.06 & $<$ & 6.61 & $\begin{array}{l}\text { If TS }<\mathrm{CV} \rightarrow \text { There is insuffi- } \\
\text { cient evidence to reject } \mathrm{H}_{0}\end{array}$ \\
\hline $\begin{array}{l}\text { Normality of the errors } \\
\mathrm{H}_{\mathrm{O}}: \text { Normally distributed }\end{array}$ & $\operatorname{adj} \operatorname{chi} 2(2)=3.21$ & 0.20 & $<$ & 5.99 & $\begin{array}{l}\text { If TS }<\mathrm{CV} \rightarrow \text { There is insuffi- } \\
\text { cient evidence to reject } \mathrm{H}_{0}\end{array}$ \\
\hline
\end{tabular}

Source: Author's calculations

\section{Plot of the residuals}

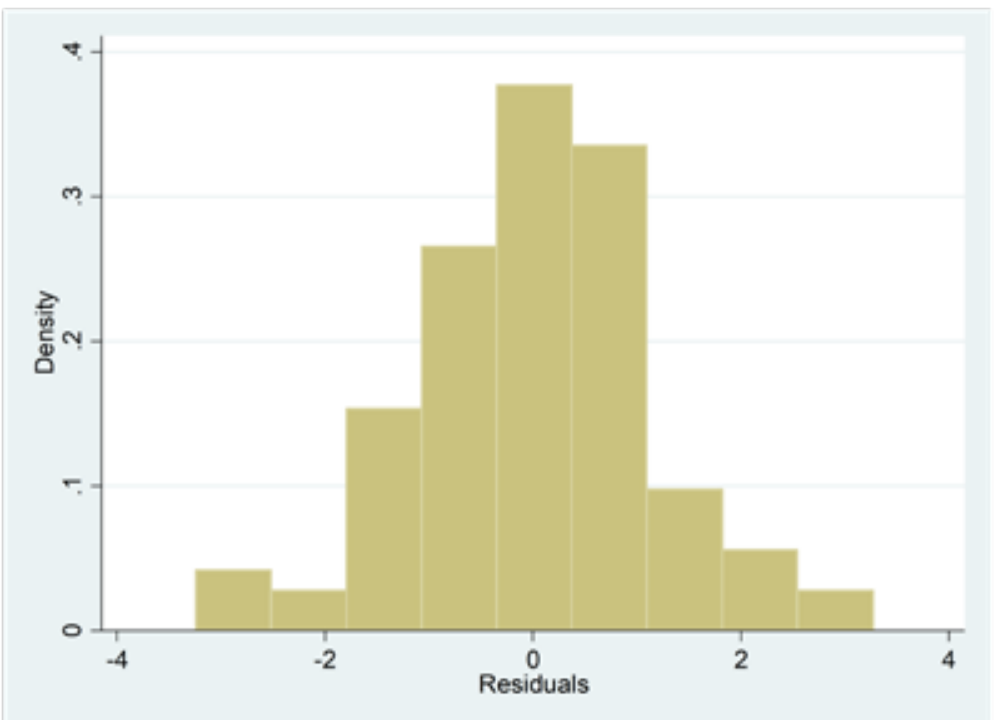

Source: Author's calculations 